\title{
Rethinking the Mississippi River diversion for effective capture of riverine sediments
}

\section{Y. JUN XU}

Louisiana State University and LSU Agricultural Center, School of Renewable Natural Resources, Baton Rouge, USA yjxu@1su.edu

\begin{abstract}
Many river deltas in the world are vibrant economic regions, serving as transportation hubs, population centres, and commercial hotspots. However, today, many of these deltaic areas face a tremendous challenge with land loss due to a number of factors, such as reduced riverine sediment supply, coastal land erosion, subsidence, and sea level rise. The development of the Mississippi River Deltaic Plain (MRDP) in southeast Louisiana, USA, over the past century is a good example. Since 1932, approximately $4877 \mathrm{~km}^{2}$ of the coastal land of MRDP has become submerged. The lower Mississippi River main channel entering the Gulf of Mexico has become an isolated waterway with both sides losing land. In contrast, large open water areas in the Mississippi River's distributary basin, the Atchafalaya River basin, have been silted up over the past century, and the river mouth has developed a prograding delta feature at its two outlets to the Gulf of Mexico. The retrospective analysis of this paper makes it clear that the main cause of the land loss in the MRDP is not the decline of riverine sediment, but the disconnection of the sediment sources from the natural flood plains. Future sediment management efforts in the MRDP should focus on restoring the natural connection of riverine sediment supplies with flood plains, rather than solely using channelized river diversion. This could be achieved through controlled overbank flooding (COF) and artificial floods in conjunction with the use of a hydrograph-based sediment availability assessment.
\end{abstract}

Key words fluvial deltas; riverine sediment; coastal geomorphology; sediment management; river engineering; Mississippi-Atchafalaya River system

\section{RIVER DIVERSION OF THE LOWER MISSISSIPPI}

The Mississippi River in the present day enters the northern Gulf of Mexico through two distributary channels: the lower Mississippi River main channel southeast of New Orleans, and the Atchafalaya River located to the west on the Louisiana central coast (Fig. 1).

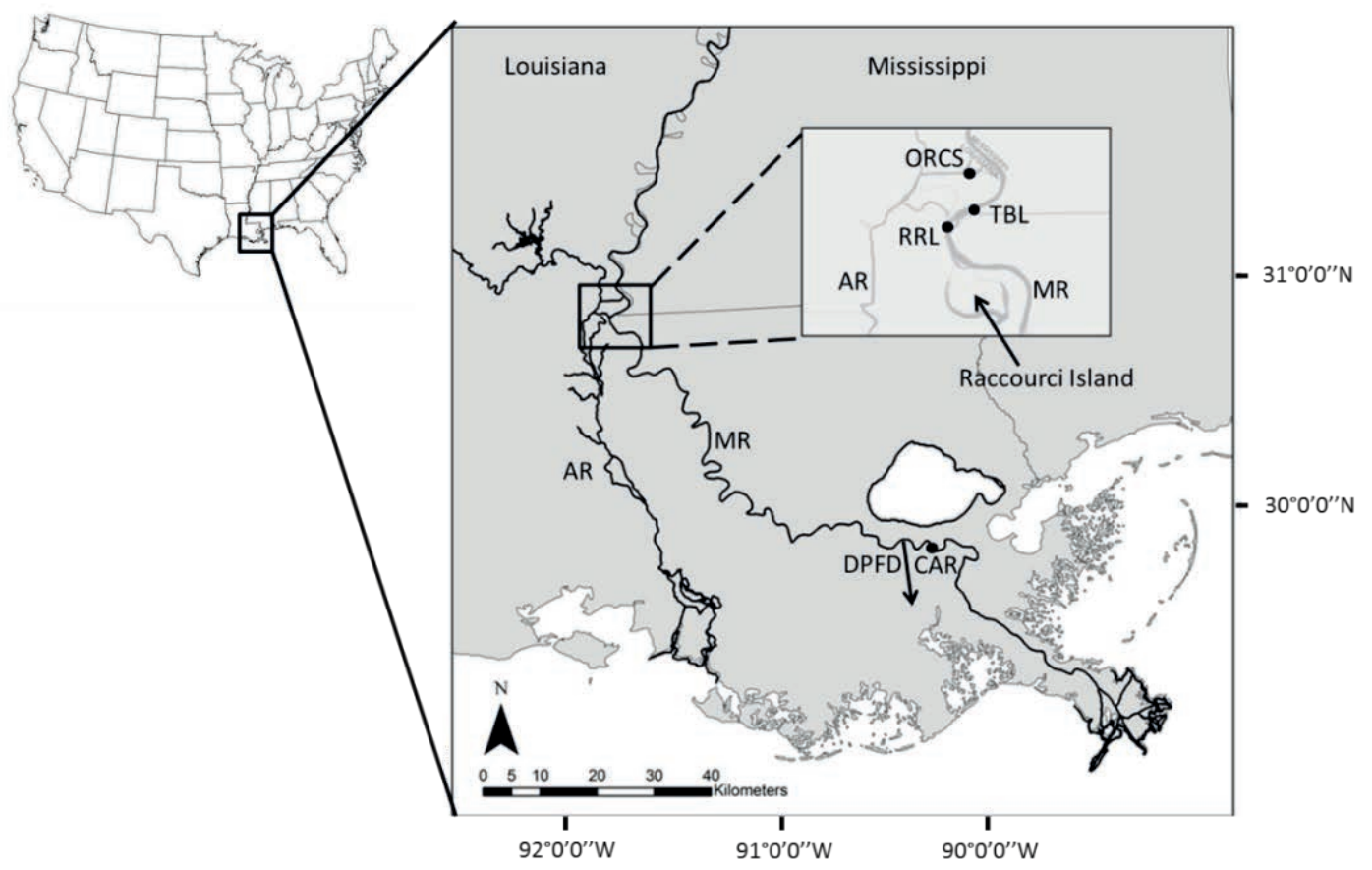

Fig. 1 The lower Mississippi River main channel (MR) and the Atchafalaya River distributary (AR). The Atchafalaya River distributary carries approximately $25 \%$ of the Mississippi River's flow and the entire flow from the Red River after the river diversion at the Old River Control Structure (ORCS). 
The lower Mississippi River main channel is approximately 500 river-km long. The Atchafalaya River is about 300 river-km shorter than the main channel as it flows almost directly southwards into the northern Gulf of Mexico. Due to the more favourable gradient, in conjunction with hydrological alterations, the better defined channel of the Atchafalaya began to form in the late 19th century, which increased the flow volume going down the Atchafalaya River (Fisk, 1952; Roberts et al., 1980). Before the early 20th century less than 10\% of the Mississippi River's flow entered the Atchafalaya. The flow ratio gradually increased, and by the 1950 s the ratio reached over $30 \%$ (Fig. 2).

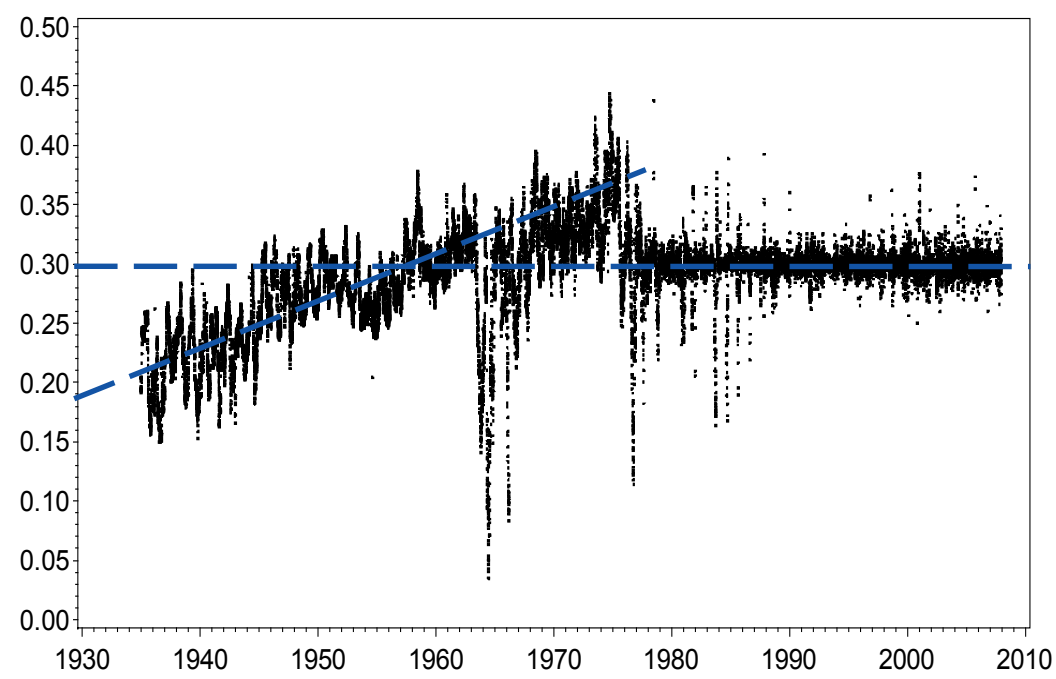

Fig. 2 Discharge ratio of the Atchafalaya distributary at Simmesport to the Mississippi River main channel at Tarbert Landing.

With the fear that the Atchafalaya River would soon capture the majority flow of the Mississippi River, construction of a river control structure (Fig 1, ORCS, the Old River Control Structure) was completed in 1963 under the Flood Control Act of 1954. Since its completion, ORCS has maintained approx. 25\% of the discharge of the Mississippi River entering the Atchafalaya River under normal flow conditions. During floods, a much higher percentage of discharge from the Mississippi is diverted into the Atchafalaya to reduce flooding risks for two major cities downriver: Baton Rouge and New Orleans.

The 500-km long lower Mississippi River main channel is narrowly confined by levees (within 1 kilometre of the channel) for navigation and flood prevention. The channel is completely disconnected from the natural flood plains (Fig. 3). In contrast, because of its use as a floodway for the Mississippi River, the 200-km long Atchafalaya River is allowed to flow through wider flood plains surrounded by levees on the east and west for about $10-35 \mathrm{~km}$. The levee-confined area, also known as the Atchafalaya River Floodway Basin, encompasses a total area of $3923 \mathrm{~km}^{2}$ (Xu, 2013) with heavily braided river channels, open water areas, wooded lowlands, cypress-tupelo surface flow swamps, and some freshwater marshes in the lower basin area. The Atchafalaya River enters the Gulf of Mexico through two outlets: the Morgan City Outlet and the Wax Lake Outlet, and they have a discharge ratios of approximately $60 \%$ and $40 \%$, respectively.

\section{LAND LOSS AND GAIN ON THE MISSISSIPPI-ATHCFALAYA DELTAIC PLAINS}

River engineering in the Mississippi-Atchafalaya Rivers has achieved its two main goals - flood control and navigation. Since 1927, no over-levee flood has occurred in the lower Mississippi River, while the engineered Mississippi-Atchafalaya River system has played its role as a critical transportation route for industry, agriculture and commerce. These have been managed at the cost of disconnecting the sediment supply to the previous flood plain (Fig. 3). The Mississippi River Delta Plain has undergone extensive land loss during the past century. Peak delta plain loss 


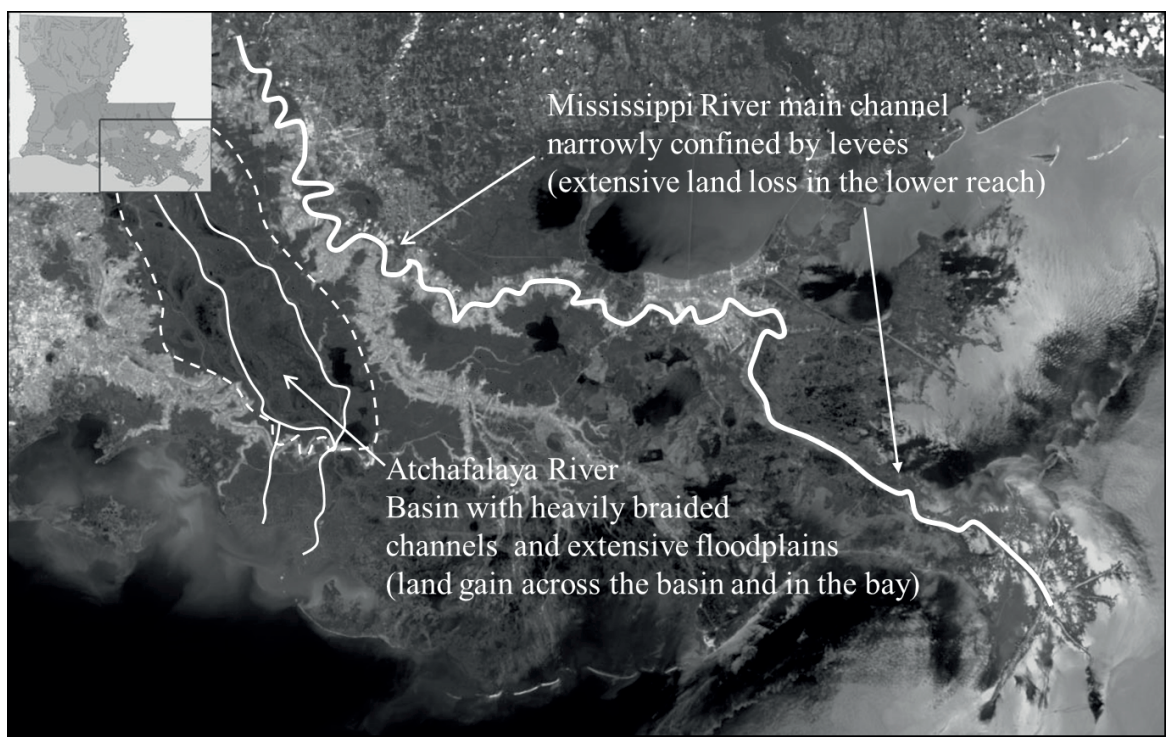

Fig. 3 Extensive land loss in the lower Mississippi River Delta and, in contrast, land gain in the Atchafalaya distributary basin and bay areas.

occurred from the mid-1950s until the 1970s at rates of 60-75 km² year'-1 (British and Dunbar, 1993; Barras et al., 2009); a total land loss of $4877 \mathrm{~km}^{2}$ has been reported for the past 70 years (Couvillion et al., 2011). The land loss has been attributed to both natural and anthropogenically exacerbated causes including the decline of riverine sediment, coastal land subsidence, erosion, and relative sea level rise.

As with many large rivers in the world, sediment loads in the lower Mississippi River near the Gulf of Mexico have also declined greatly in the past century (Meade \& Moody, 2010). The combined annual yield of suspended sediment from the Mississippi River main channel and the Atchafalaya River dropped from levels of 400 million tonnes in the 19th century to an average of 180 million tonnes in the recent two decades (Fig. 4). The riverine sediment decline has frequently been named in the literature as the major cause for the rapid land loss, along with other factors such as subsidence and sea level rise. However, the geomorphological development of the Atchafalaya River Basin and the river's mouth over the past century does not support the reasoning.

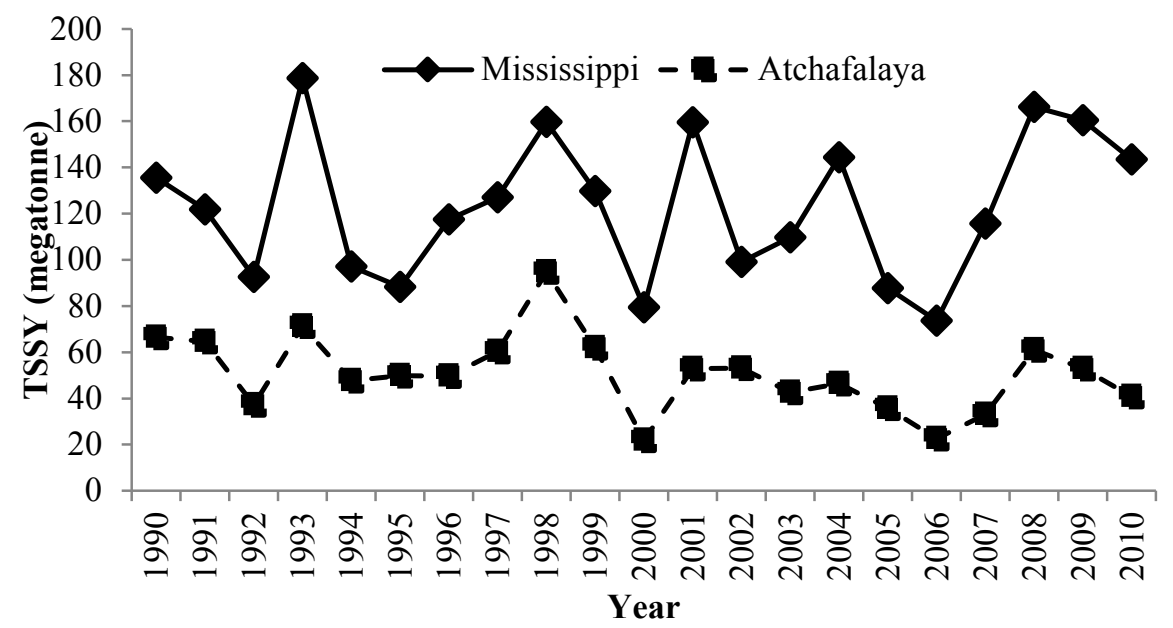

Fig. 4 Total suspended sediment yields (TSSY) of the Mississippi River at Tarbert Landing ( 120 Mt year $\left.{ }^{-1}\right)$ and Atchafalaya River at Simmesport ( $\left.60 \mathrm{Mt}^{-1} \mathrm{Mr}^{-1}\right)$ during the recent two decades. 
In contrast to the rapid land loss in the Mississippi River main channel delta, the Atchafalaya River Basin and the river mouth have been gaining land steadily in the past century. In the 19th century, the Atchafalaya River Basin consisted largely of open water and swampy areas. As the river channel was cleaned with increasing flow from the Mississippi River, the open water areas in the basin began accumulating sediments, losing much of its open water and swamp habitat to lacustrine delta formations (Tye \& Coleman, 1989). In the 1950s, with the open water areas sediment-filled, formation of subaqueous deltas at the two outlets of the Atchafalaya River, Morgan City main channel (ARMC) and Wax Lake Outlet (WLO), became noticeable (Shlemon, 1975). Sub-aerial land started forming in 1972 and was accelerated by large floods that occurred from 1973 to 1975, forming the Atchafalaya River subdelta (ARSD) and Wax Lake Outlet subdelta (WLSD) (Roberts et al., 1980). With sub-aerial delta formation, vegetation succession was able to begin with emergent plants colonizing the delta islands once they reached intertidal elevations. By 1979, the Atchafalaya River Delta Complex (i.e. ARDC $=$ ARSD + WLSD) had over $16 \mathrm{~km}^{2}$ vegetated area (Johnson et al., 1985). Over the past 30 years, the ARDC continued to grow with a net prograding rate of approximately $3 \mathrm{~km}^{2}$ year ${ }^{-1}$ (Xu, 2010; Rosen \& Xu, 2013), while the basin area continued to be silted up at a sedimentation rate of $44 \mathrm{~mm}$ year ${ }^{-1}$ (Rosen \& $\mathrm{Xu}, 2014)$.

\section{LESSONS FROM THE PAST RIVER DIVERSIONS}

Over the past two decades, various restoration projects have been developed to impede land loss in the Mississippi River Deltaic Plains. These include, among others, three large river diversions for the sole purpose of restoration in southeast Louisiana: Caernarvon, Davis Pond (DPFD) and West Bay. The first two were constructed to introduce freshwater to reduce estuarine salinity, while the latter was designed to bring sediment to the disappearing wetlands.

Caernarvon Diversion Outfall Management Project, located on the east bank of the Mississippi River at the river-kilometre of 132 (river mile 82), was opened in August 1991 and was capable of discharging $227 \mathrm{~m}^{3} \mathrm{~s}^{-1}$ of freshwater to Breton Sound Basin (Sable \& Villarrubia, 2011). Davis Pond Freshwater Diversion (DPFD, see Fig. 1), located on the west bank of the Mississippi River at river kilometre 190 (river mile 118), has been in operation since July 2002 and is capable of introducing a maximum of $302 \mathrm{~m}^{3} \mathrm{~s}^{-1}$ of freshwater to Barataria Basin (LDNR, 2005). The current diversion at both locations is based on salinity, with lower salinity during the spring (higher discharge) and higher salinity during the summer and autumn (lower discharge); the diversions are continuous to maintain the salinity gradient. Despite careful planning and many years of operation, a recent study (Kearney et al., 2011) found that from 1984 to 2005 there were no significant changes in either relative vegetation or overall marsh area in zones closest to the diversion inlets. At Caernarvon Diversion, the lack of positive response to the long-term diversions has been attributed to inappropriate timing and quantity of discharge to carry sediment across the marsh, while DPFD is too small and channelized to induce sheet flow (OCPR, 2010), and/or overloading of nutrients is affecting sediment stability (Snedden et al., 2007; Kearney et al., 2011). After Hurricanes Katrina and Rita in 2005, these areas sustained even larger losses in vegetation and overall marsh area when compared to similar marshes of the adjacent reference sites (Howes et al., 2010; Kearney et al., 2011).

The West Bay Sediment Diversion was designed for sediment capture. Completed in November 2003 on the west bank of the Mississippi at the river kilometer of 4.7 (river mile 2.9, $\sim 7.6 \mathrm{~km}$ from the Head of Passes), it had a planned discharge of $396 \mathrm{~m}^{3} \mathrm{~s}^{-1}$ when the Mississippi River main channel was at 50\% discharge, but since construction the diversion has increased to $765 \mathrm{~m}^{3} \mathrm{~s}^{-1}$ (Carter, 2003; USACE, 2009). It has been reported that the diversion could be impacting navigational interests in the area while not producing the desired land growth (Barras et al., 2009; Brown et al., 2009; Heath et al., 2010). In recent years, new sediment diversions further up river have been proposed or are currently under study. However, these plans lack guidelines that can effectively address various interests, such as maintaining navigation and managing fisheries and wetlands, while still efficiently using diversions to capture sediment. 


\section{THINKING OUTSIDE OF THE BOX}

The Mississippi-Atchafalaya River Deltaic Plains are home to over 2 million people. The region is rich with natural resources and contributes $25 \%$ to the US energy supply and $25 \%$ to the US fisheries products while also serving as a transportation hub and commercial centre. The current land loss is a great threat to the communities living in, and the economy supported by, the region. Protection and restoration of the coastal land are ultimately top priorities in Louisiana.

The above retrospective analysis of the Mississippi-Atchafalaya Rivers and the dynamics of their deltaic areas demonstrate that the reduction of sediment loads from the upper river basin should not be considered as the major cause for the past-century land loss in coastal Louisiana. The disconnection of river channels from natural flood plains by channelization and levee construction have played a major role in the land loss, as they have constrained the continuous sediment supply needed for the deltaic land. River diversion efforts in recent decades have likewise not been successful in creating new land. If future management of the MississippiAtchafalaya rivers continues as present day, there is little doubt that the lower Mississippi River Delta will continue to sink. To offset the widespread land loss in the region, new approaches that can effectively capture riverine sediments in the lower Mississippi River must be developed for large-scale application.

\section{Controlled Overbank Flooding (COF) for large-scale sediment diversion}

One such new approach, proposed by Xu \& Rosen (2012), is to use controlled overbank flooding to effectively capture riverine sediment. Many studies have found high sedimentation rates of coarse particles during floods on flood plain areas bordering the river channel. Natural overbank flow has been documented to benefit river-flood-plain systems, marshland, and fisheries. Controlled overbank flow can be implemented by lowering a stretch of river levee, as illustrated in Fig. 5. The flow will act as through a rectangular weir, whose flow rate can be approximated as a function of hydraulic head. Assuming that overbank flow spills over the land in a sectorial shape (Fig. 5), the flooded area and time needed for the flood depend on a number of factors including hydraulic head, width of the lowered levee, topography, soil physical characteristics and vegetation of the land.
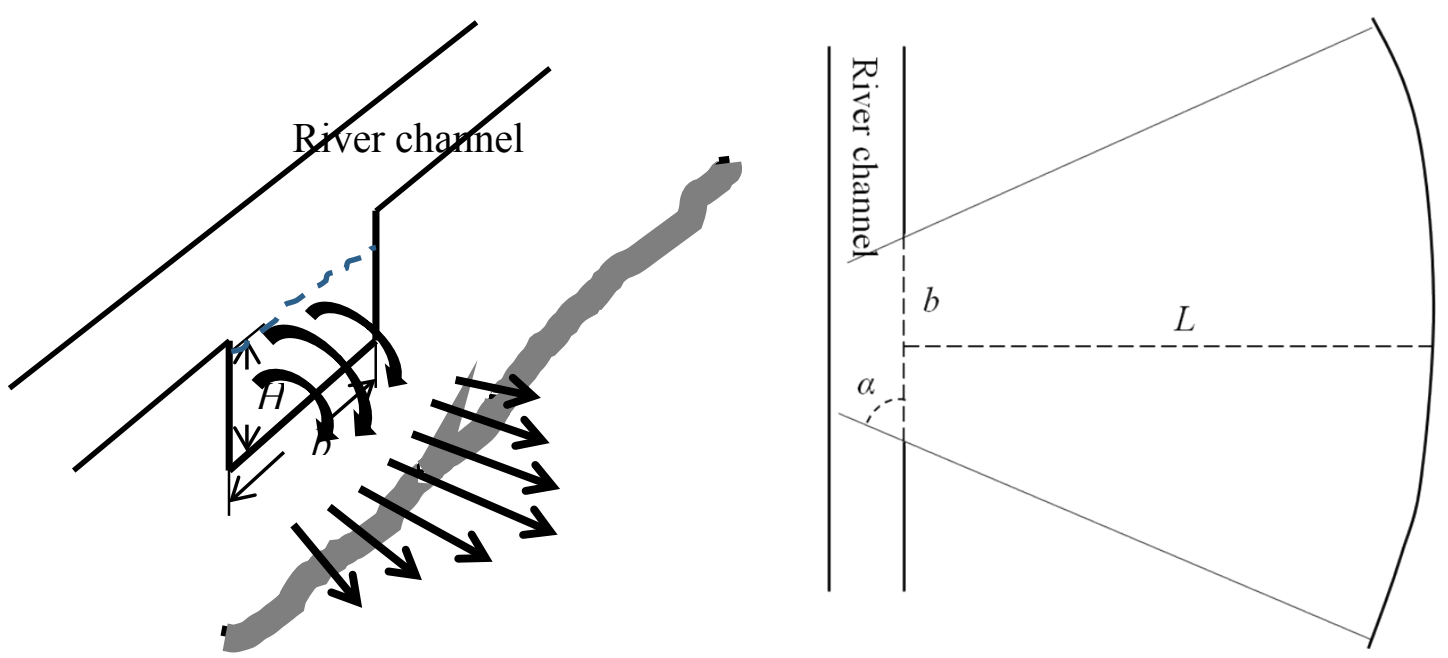

Fig. 5 Diagram of controlled overbank flows via a lowered levee and the geometry of the hypothetical sectorial flooding area.

Based on the geometry, equations (1) and (2) can be used to determine the sectorial flooding area $(A)$ and overbank flow rate $(Q)$ below, respectively:

$$
A=\frac{\beta}{2}\left\{b /\left[2 \times \tan \left(\frac{\beta}{2}\right)\right]+L\right\}^{2}-b^{2} /\left[4 \times \tan \left(\frac{\beta}{2}\right)\right]
$$


where $\beta=180-2 \alpha$ in radians, $b=$ overbank flow width, and $L=$ distance from the bank to the flood front edge, and:

$$
Q=k \frac{2}{3} \sqrt{2 g} b H^{2 / 3}
$$

where $k=$ discharge coefficient, $g=$ gravitational acceleration, $b$ and $H$ are the width and hydraulic head (Fig. 5), respectively.

With the information on $A$ and $Q$, flow volume and time can be estimated for a certain flooding depth. With information on riverine sediment concentration, the amount of sediments that may be captured during an overbank flooding event can be estimated. The COF approach may be tested on south levees along the Gulf Intracoastal Waterway.

\section{Creation of artificial floods for continuous delta progression}

Deltaic land creation in the Atchafalaya River Deltaic Complex has been found to be dictated by major floods (>13 $800 \mathrm{~m}^{3} \mathrm{~s}^{-1}$, Rosen \& Xu, 2013, Table 1). Large floods in the Atchafalaya River were able to transport substantial quantities of sediment (especially coarse sediment) needed to create sub-aerial land formation, which was followed by vegetation colonization, stabilizing the newly created land. The finding was also confirmed in the recent study by Carle et al. (2014) that found a large area of newly created land with vegetation in the ARDC following the 2011 river flood. While new land is created by sediment, part of the submerged land is also lost to storm surge caused by hurricanes. The net change is positively related to the number of major floods. This is especially apparent in the deltaic development of the ARDC in the past decade (Table 1): a net land loss of $2 \mathrm{~km}^{2}$ during 2000-2004 with no major floods and an annual SSY of $43 \mathrm{Mt} \mathrm{year}^{-1}$ versus a net land gain of $13 \mathrm{~km}^{2}$ during 2005-2010 with a similar SSY (42 Mt year ${ }^{-1}$ ) but three major floods. Based on these findings, Rosen \& Xu (2013) postulated that future growth and stabilization of the ARDC will mostly depend on floods of the Atchafalaya River.

In the recent decade, the Atchafalaya River delivered approximately $43 \mathrm{Mt}$ of suspended sediment annually to the Atchafalaya Bay. This quantity of sediment could theoretically create a volume of 43 million $\mathrm{m}^{3}$ of sediment (assuming a bulk density of 1 tonnes $\mathrm{m}^{-3}$ for fresh sediment deposit), or a $43-\mathrm{km}^{2}$ land area with $1-\mathrm{m}$ sediment deposit. A change in either the volume or timing of the discharge diverted into the Atchafalaya will have effects on the development of the Atchafalaya River Deltaic Complex. Because of the critical role of floods in delta progression, future management of the lower Mississippi River should consider creating artificial floods for the Atchafalaya to maximize capturing of sediment.

Table 1 Land gain and loss in the Atchafalaya Deltaic Complex in relation with annual suspended sediment yield (SSY) and the number of major floods and hurricanes (Data sources from Rosen \& Xu, 2013).

\begin{tabular}{|c|c|c|c|c|c|c|}
\hline Period & $\begin{array}{l}\text { SSY } \\
\left(\text { Mt year }^{-1}\right)\end{array}$ & $\begin{array}{l}\text { No. of floods } \\
\text { (per year) }\end{array}$ & $\begin{array}{l}\text { No. of hurricanes } \\
\text { (per year) }\end{array}$ & $\begin{array}{l}\text { Land gain } \\
\left(\mathrm{km}^{2}\right)\end{array}$ & $\begin{array}{l}\text { Land loss } \\
\left(\mathrm{km}^{2}\right)\end{array}$ & $\begin{array}{l}\text { Net change } \\
\left(\mathrm{km}^{2} \text { year }{ }^{-1}\right)\end{array}$ \\
\hline 1989-1995 & 56 & $5(0.7)$ & $2(0.3)$ & 37.3 & 3.7 & 5.8 \\
\hline 1996-1999 & 67 & $2(0.5)$ & $4(1.0)$ & 24.1 & 9.5 & 4.9 \\
\hline 2000-2004 & 43 & $0(0.0)$ & $3(0.5)$ & 14.5 & 16.6 & -0.4 \\
\hline 2005-2010 & 42 & $3(0.5)$ & $6(1.0)$ & 20.0 & 7.1 & 2.2 \\
\hline
\end{tabular}

\section{Application of a hydrograph-based sediment availability approach}

Rosen and Xu (2014) recently developed a hydrograph-based accounting of sediment availability for the lower Mississippi River main channel (Fig. 6) based on the long-term relation of suspended sediment yields with the river's hydrological conditions. They quantified suspended sediment loadings (SSL) for three river stages of the Mississippi River main channel at Tarbert Landing (commonly used by the US federal agency NOAA for flood forecasting): Peak Flow Stage (stage $=16.7 \mathrm{~m}$, discharge $>32000 \mathrm{~m}^{3} \mathrm{~s}^{-1}$ ), High Flow Stage $($ stage $=14.6 \mathrm{~m}$, discharge $=25000-32000$ $\left.\mathrm{m}^{3} \mathrm{~s}^{-1}\right)$, and Intermediate Flow Stage $\left(\right.$ stage $=12.0 \mathrm{~m}$, discharge $\left.=18000-25000 \mathrm{~m}^{3} \mathrm{~s}^{-1}\right)$. The 
study found that although Peak Flow Stage had the largest volume of discharge, the river water showed a significantly lower suspended sediment concentration (SSC), indicating that diversion of the river at this stage would be less effective for sediment capture. The lower Mississippi River showed significantly higher SSC and SSL during the rising than the receding limb. When the flood pulse was rising, the Intermediate Flow and High Flow Stages showed greater SSC and SSL than Peak Flow Stage. Together, Intermediate Flow and High Flow Stages on the rising limb annually discharged $29 \mathrm{Mt}$ over approximately 42 days, identifying this to be the best period for sediment capture and diversion.

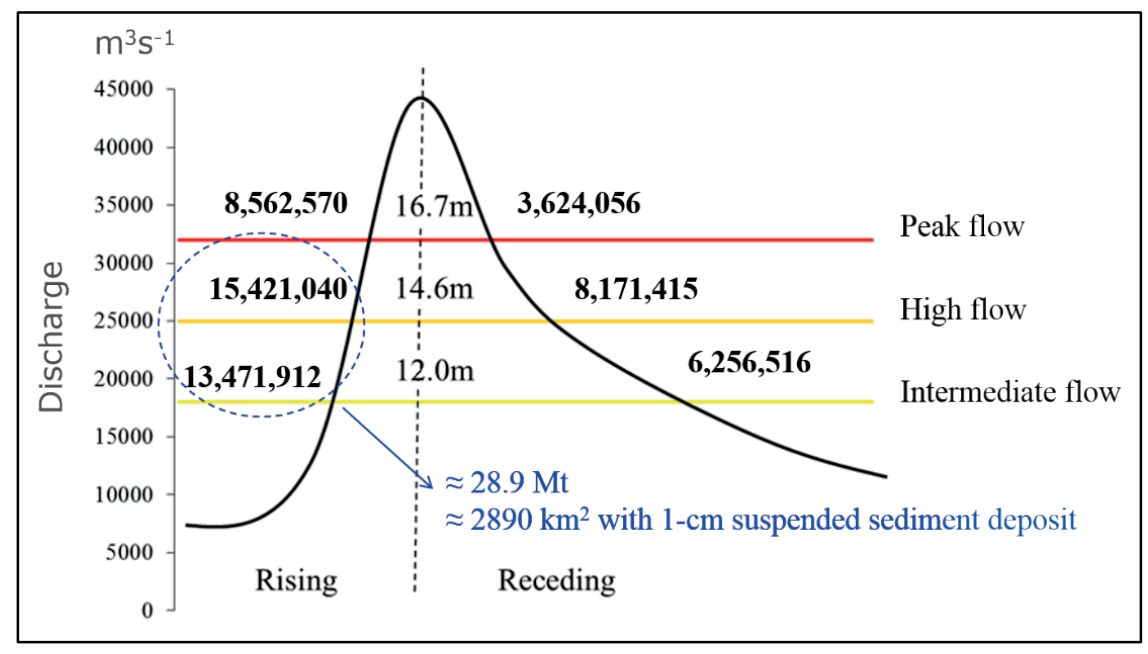

Fig. 6 Annual suspended sediment loadings (megatonnes, or $\mathrm{Mt}$ ) in relation to river stage, discharge and flow conditions of the Mississippi River main channel at Tarbert Landing $(\sim 500 \mathrm{~km}$ from the river mouth to the Gulf of Mexico). SSL is higher on the rising limb than on the receding limb. The sum of SSL from the Intermediate Flow and High Flow stages on the rising limb $(28.9 \mathrm{Mt})$ is nearly $25 \%$ of the annual total SSL of the Mississippi River, which could create a land area of $2890 \mathrm{~km}^{2}$ with $1-\mathrm{cm}$ deep deposit of suspended sediment (assuming a fresh sediment bulk density of 1 tonne $\mathrm{m}^{-3}$ ) if captured on land.

Application of the hydrography-based approach is critical for determining the actual availability of riverine sediment due to the variability of the quantity and timing of total suspended sediment during Mississippi River flood pulses. This can be completed for other river locations where sediment diversion is considered, and can be especially helpful for application of the controlled overbank flooding and artificial floods as described previously. Knowing that discharge during the rising limbs of Intermediate Flow Stage and High Flow Stage provides the greatest amount of sediment, managers can effectively operate diversions based on predictions of the timing of a flood pulse moving down the Mississippi River.

\section{CONCLUSIONS}

Riverine sediment decline is not the main cause for the land loss of the Mississippi River Delta, but it is the disconnection of the river channels with natural flood plains by levee constructions that has constrained the continuous sediment supply needed for stabilization and creation of coastal land. Although river diversions have been constructed in the past two decades, neither of them has been successful in creating new land or maintaining disappearing wetlands. To prevent further land loss and create new land in coastal Louisiana, the author believes that new approaches for effectively utilizing riverine sediments in the lower Mississippi River must be developed and suggests that the following approaches be considered in future lower Mississippi-Atchafalaya River management:

(1) Application of controlled overbank floodings that mimic natural processes of sediment replenishment over the broad coastal areas rather than through channelized river diversions to a few small bay areas. 
(2) Creation of artificial floods periodically in the Atchafalaya River for progradation and stabilization of the Atchafalaya River Delta Complex.

(3) Utilization of a hydrograph-based accounting of sediment availability that can identify actual divertable sediment quantity under different river hydrological regimes.

Acknowledgements The author thanks the United States Army Corps of Engineers and United States Geological Survey for making long-term data on river discharge and suspended sediment concentration available. This research was partly supported by an award from the US National Science Foundation (award number: 1212112). The paper represents the views of its author solely.

\section{REFERENCES}

Carle, M.V., Sasser, C.E. \& Roberts, H.H. (2014) Accretion and vegetation community change in the Wax Lake Delta following the historic 2011 Mississippi River flood. Journal of Coastal Research (in press).

Couvillion, B.R., et al. (2011) Land area change in coastal Louisiana from 1932 to 2010. US Geological Survey Scientific Investigations Map 3164, scale 1:265,000. United States Geological Survey, 12p.

Barras, J., Padgett, W.C. \& Sanders, C.B. (2009) Aerial and bathymetric spatial change analysis of the West Bay Diversion receiving area, Louisiana, for U.S. Army Engineer District, New Orleans (MVN), Report MR-03, pp. 1-39, Mobile District Operations Division, Spatial Data Branch, Mobile, Alabama.

Britsch, L. D. \& Dunbar, J. B. (1993) Land loss rates: Louisiana coastal plain. J. Coastal Res. 9, 324-338.

Brown, G., et al. (2009) ERDC Workplan Report-Draft, West Bay Sediment Diversion Effects, Coastal and Hydraulics Laboratory U.S Army Engineer Research and Development Center, Vicksburg, MS, 263pp.

Carter, B. (2003) Monitoring Plan for West Bay Sediment Diversion State Project Number MR-03, Coastal Protection and Restoration Authority of Louisiana, Office of Coastal Protection and Restoration, New Orleans, 12pp.

Fisk, H.N. (1952) Geological Investigation of the Atchafalaya Basin and the Problem of Mississippi River Diversion. Mississippi River Commission, Vicksburg, MS (145 pp.).

Heath, R.E., Sharp, J.A. \& Pinkard Jr ,C.F. (2010) 1-Dimensional modeling of sedimentation impacts for the Mississippi River at the West Bay Diversion, paper presented at 2nd Joint Federal Interagency Conference, Las Vegas, NV.

Howes, N.C., et al. (2010) Hurricane-induced failure of low salinity wetlands. PNAS 107(32), 14014-14019, doi:10.1073/pnas.0914582107.

Johnson, W.B., Sasser, C.E. \& Gosselink, J.G. (1985) Succession of vegetation in an evolving river delta, Atchafalaya Bay, Louisiana. Journal of Ecology 73 (3), 973-986.

Kearney, M.S., Alexis Riter, J. C. \& Turner, R.E. (2011) Freshwater river diversions for marsh restoration in Louisiana: Twenty-six years of changing vegetative cover and marsh area. Geophysical Research Letters 38, L16405, 1-6, doi:10.1029/2011GL047847.

LDNR. (2005) Davis Pond freshwater diversion project annual report 2003-2004. Louisiana Department of Natural Resources, Baton Rouge, LA, $51 \mathrm{pp}$.

Meade, R. H. \& Moody, J. A. (2010) Causes for the decline of suspended-sediment discharge in the Mississippi River system, 1940-2007. Hydrol. Processes 24, 35-49.

OCPR. (2010) Davis Pond Freshwater Diversion Project draft annual report 2007-2009, pp 1-23, Office of Coastal Protection and Restoration, Louisiana Department of Natural Resources, Baton Rouge, LA.

Roberts, H.H., Adams R.D. \& Cunningham R.H.W. (1980) Evolution of sand-dominant subaerial phase, Atchafalaya delta, Louisiana. American Association of Petroleum Geologists 64(2), 264-279.

Rosen, T. \& Xu, Y.J. (2013) Recent decadal growth of the Atchafalaya River Delta complex: effects of variable riverine sediment input and vegetation succession. Geomorphology 10.1016/j.geomorph.2013.04.020.

Rosen, T. \& Xu, Y.J. (2014) A hydrograph-based sediment availability assessment: Implications for Mississippi River sediment diversion. Water, 6, 564-583; doi:10.3390/w6030564.

Rosen, T. \& Xu, Y. J. (2014) Estimation of sedimentation rates in the distributary basin of the Mississippi River, the Atchafalaya River Basin, USA. Hydrology Research doi: 10.2166/nh.2013.181. (in press)

Sable, S.E. \& Villarrubia, C. (2011) Analysis of fisheries-independent data for evaluation of species distribution responses to the Caernarvon freshwater diversion, Louisiana Applied Coastal Engineering and Science Division, Office of Coastal Protection and Restoration, Baton Rouge, LA, 86 pp.

Shlemon, R. J. (1975) Subaqueous delta formation - Atchafalaya Bay, Louisiana. In: Deltas (ed. by M. L. Broussard). Houston Geological Society, Huston, Texas, 209-221.

Snedden, G.A., et al. (2007) Sediment discharge into a subsiding Louisiana deltaic estuary through a Mississippi River diversion. Estuarine Coastal and Shelf Science 71, 181-193, doi: 10.1016/j.ecss.2006.06.035.

Tye, R.S. \& Coleman J.M. (1989) Depositional processes and stratigraphy of fluvially dominated lacustrine deltas: Mississippi Delta Plain. Journal of Sedimentary Petrology 59(6), 973-996.

USACE. (2009) Fact sheet West Bay sediment diversion (MR-03), United States Army Corps of Engineers and Louisiana Department of Natural Resources, $2 \mathrm{pp}$.

Xu, Y.J. (2010) Long-term sediment transport and delivery of the largest distributary of the Mississippi River, the Atchafalaya, USA. In: Sediment Dynamics for a Changing Future (ed. by K. Banasik, et al.) 282-290, IAHS Publ. 337, Wallingford, UK.

$\mathrm{Xu}$, Y.J. (2013) Transport and retention of nitrogen, phosphorus, and carbon in North America's largest river swamp basin, the Atchafalaya River Basin. Water 5, 379-393.

Xu, Y.J. \& Rosen, T. (2012) Are riverine sediment discharges sufficient to offset the sinking coast of Louisiana? In: Erosion and Sediment Yields in the Changing Environment (ed. by A. Collins et al.), 104-113, IAHS Publ. 356, Wallingford, UK. 